\title{
PENERAPAN METODE QUESTION STUDENT HAVE DALAM UPAYA PENINGKATAN KEAKTIFAN DAN HASIL BELAJAR SISWA PADA PEMBELAJARAN KONSEP VIRUS DI MAN 4 PIDIE
}

\author{
Erlina
}

Pendidikan Biologi MAN 4 Pidie

\begin{abstract}
ABSTRAK
Penelitian ini merupakan penelitian tindakan kelas (Classroom Action Research), yaitu penelitian yang dilakukan pada sebuah kelas untuk mengetahui akibat tindakan yang diterapkan pada suatu subjek penelitian di kelas tersebut. Pada awal penelitian tindakan menjadi salah satu model penelitian yang dilakukan pada bidang pekerjaan tertentu dimana peneliti melakukan pekerjaannya, baik dibidang pendidikan, kesehatan, maupun pengelola sumber daya manusia. Salah satu contoh pekerjaan utama dalam bidang pendidikan adalah mengajar di kelas. Dengan demikian yang menjadi subjek penelitian adalah situasi di kelas, individu siswa, atau di sekolah. Dengan subjek dalam penelitian ini adalah siswa kelas X IPA 2 MAN 4 Pidie yang berjumlah 26 siswa. Pembatasan ruang lingkup ini bertujuan untuk memudahkan peneliti dalam mengumpulkan dan mengelola informasi dikarenakan ruang lingkupnya tidak terlalu luas, di samping itu dengan pembatasan subjek peneliti pada satu kelas, akan menghemat waktu yang peneliti gunakan. Berdasarkan hasil pegolahan data terlihat bahwa kemampuan guru dalam mengelola pembelajaran berada pada kategori sangat baik sesuai dengan perolehan nilai 3,80. Hal ini karena guru yang merupakan peneliti sudah mempersiapkan perangkat pembalajaran question student have secara cermat. Kemampuan guru melakukan perbaikan-perbaikan melalui refleksi setelah pertemuan pembelajaran berlangsung merupakan faktor penting agar dapat lebih baik pada pertemuan berikutnya. Respon yang diberikan siswa terhadap pembelajaran materi virus dengan menggunakan metode pembelajaran question student have sangat baik. Hal ini sesuai dengan hasil angket dengan nilai 83,33 \% yang menyatakan bahwa senang terhadap kegiatan pembelajaran tersebut. Rasa sengang siswa terhadap pembelajaran menunjukkan bahwa pembelajaran ini menimbulkan rasa puas bagi siswa. Rasa senang siswa juga disebabkan oleh untuk bekerja sama dalam kelomok dalam menyelesaikan tugas pada LKS dengan persentase $15 \%$ pada setiap RPP. Kata Kunci :_Question Student Have, Pembelajaran Konsep Virus.
\end{abstract}

\section{Latar Belakang Masalah}

Pendidikan merupakan salah satu
faktor penting dalam menunjang kelangsungan hidup manusia di muka bumi. Agar dapat hidup sesuai dengan martabat, maka manusia perlu mengetahui bahkan menguasai banyak hal. Di samping itu, pendidikan juga sebagai kebutuhan rohani yang harus dipenuhi. Untuk itu, manusia harus belajar agar dapat mengembangkan bakat, minat dan kepribadian yang sesuai dengan kemampuan yang dimilikinya.

Setiap proses belajar mengajar mempunyai tujuan yang ingin dicapai. Tujuan tersebut akan tercapai apabila ada kerja sama antara beberapa komponen di antaranya: guru, siswa, materi pelajaran, metode, media, evaluasi dalam proses belajar mengajar. Dalam proses belajar mengajar, guru merupakan orang yang bertanggung jawab membawa siswa pada suatu taraf kematangan tertentu. Oleh karena itu dalam proses belajar mengajar guru harus berusaha menempuh berbagai cara demi tercapainya tujuan pendidikan. Untuk memperoleh hasil dari proses pembelajaran terhadap siswa, sangat dibutuhkan guru yang memiliki kompetensi yang memadai. Sesuai dengan pendapat Raharja bahwa: "hasil belajar yang bermutu hanya mungkin dapat dicapai 
melalui proses belajar yang bermutu". Jika proses belajar tidak optimal sangat sulit diharapkan terjadinya hasil belajar yang optimal pula. Pendekatan belajar dan strategi melaksanakan pendekatan serta metode belajar termasuk faktor-faktor yang turut menentukan keberhasilan belajar siswa.

Menurut Syah Muhibbin bahwa pencapaian prestasi belajar selama ini di sekolah dapat dilatarbelakangi oleh sejumlah faktor meliputi: 1) keadaan atau kondisi jasmani dan rohani siswa, seperti sikap siswa, bakat siswa, dan motivasi belajar siswa, 2) kondisi lingkungan di sekitar siswa, seperti keluarga, guru, sarana prasarana, sekolah dan 3) tanggung jawab belajar siswa sebagai pelajar di sekolah maupun di rumah.

Biologi merupakan suatu ilmu pengetahuan yang mempelajari tentang seluk-beluk makhluk hidup. Biologi membantu manusia mengenal dirinya sebagai organisme, mengenal lingkungannya dan hubungan antara organisme dengan lingkungan. Tujuan pengajaran biologi antara lain mengembangkan cara berpikir ilmiah melalui penelitian dan percobaan, mengembangkan pengetahuan praktis dan metode biologi untuk memecahkan masalah kehidupan individu dan sosial.

Metode yang baik adalah metode yang dapat digunakan oleh guru dalam rangka mengajarkan anak didiknya untuk mencapai tujuan pengajaran yang telah ditetapkan dalam pengajaran atau pembelajaran. Metode tidak dapat dianggap sesuatu hal yang mudah, karena metode memiliki peran penting dalam pencapaian tujuan. Banyak metode yang dapat digunakan dalam menerapkan active learning (belajar aktif) dalam pembelajaran di sekolah. Mel Sibelmen mengemukakan berbagai metode dalam pembelajaran aktif, yaitu 101 bentuk metode yang dapat digunakan dalam pembelajaran aktif. Kesemuanya dapat diterapkan dalam pembelajaran di kelas sesuai dengan jenis materi yang diinginkan dapat tercapai, salah satunya adalah question student have atau pertanyaan peserta didik yaitu suatu metode dalam proses pembelajaran aktif dengan cara belajar berawal dari pertanyaan.

Berdasarkan hasil Observasi bahwa siswa kurang aktif dalam belajar khususnya pada pembalajaran konsep virus. Metode yang sering digunakan adalah ceramah, sehingga prestasi siswa pada konsep tersebut rendah. Nilai yang tertinggi 88 , nilai yang terendah 19 dan nilai kelulusannya 16 orang, sedangkan nilai yang tidak lulus 12 orang dari 28 siswa dengan nilai rata-rata 60,9. Respon siswa terhadap prestasi belajar yang dilalui guru pada konsep virus juga rendah. Perhatian siswa pada materi virus dalam proses belajar mengajar di kelas hanya sekitar 50\% saja. Hanya sebagian kecil dari siswa yang memiliki minat yang tinggi dalam mempelajari materi virus.

Hal ini mendorong penulis untuk melakukan penelitian tentang pembelajaran dengan menggunakan metode question student have (QSH) ini pada konsep virus di sekolah MAN 4 Pidie, sehingga dapat memberikan nuansa belajar yang berbeda dari yang biasanya dilakukan. Metode ini sangat baik digunakan pada siswa yang kurang berani mengungkapkan pertanyaan, keinginan dan harapan-harapannya melalui percakapan. Metode question student have (pertanyataan peserta didik) ini digunakan untuk mempelajari tentang keinginan dan harapan anak didik sebagai dasar untuk memaksimalkan potensi yang mereka miliki.

\section{Rumusan Masalah}

Sehubungan dengan permasalahan di atas maka yang menjadi permasalahan pada penelitian ini adalah:

1. Apakah ada peningkatan prestasi belajar siswa setelah penerapan metode question student have pada pembelajaran konsep virus di MAN 4 Pidie?

2. Bagaimana respon siswa di MAN 4 Pidie dalam kegiatan belajar mengajar pada 
konsep virus melalui metode question student have?

\section{Tujuan Penelitian}

Sesuai dengan rumusan masalah di atas, maka tujuan penelitian ini:

1. Untuk mengetahui peningkatan prestasi belajar siswa pada konsep virus melalui penerapan metode question student have di MAN 4 Pidie.

2. Untuk mengetahui respon siswa terhadap pembelajaran konsep virus dengan penerapan metode question student have di MAN 4 Pidie.

\section{KAJIAN TEORITIS}

A. Pengertian Metode Question Student Have

Metode Question Student Have adalah metode yang digunakan untuk mempelajari tentang keinginan dan harapan anak didik sebagai dasar untuk memaksimalkan potensi yang mereka miliki. Metode ini menggunakan sebuah tekhnik untuk mendapatkan partisipasi siswa melalui tulisan. Hal ini sangat baik digunakan pada siswa yang kurang berani mengungkapkan pertanyaan, keinginan dan harapanharapannya melalui percakapan.

B. Pengertian Media Dalam Pembelajaran Biologi

Media dapat pula mencerminkan pengertian bahwa setiap sistem pengajaran yang melakukan peran media di mulai dari guru sampai kepada peralatan paling canggih, lebih ringkasnya, media adalah alat yang menyampaikan atau mengantarkan pesan-pesan pengajaran.

Kata media berasal dari bahasa latin yaitu medius yang secara harfiah berarti tengah, perantara atau pengantar. Dalam bahasa Arab, media adalah perantara (وسلئل) atau pengantar pesan dari pengirim kepada penerima pesan. Media pembelajaran merupakan seperangkat alat bantu yang mengatur hubungan yang efektif antara dua dan isi pengajaran.

Heinich, dkk (1982) Dalam buku Azhar Arsyad mengemukakan istilah medium sebagai perantara yang mengantar informasi antara sumber dan penerima. Jadi, televisi, film, foto, radio, rekaman audio, gambar yang diproyeksikan, bahan-bahan cetakan, dan sejenisnya adalah media komunikasi. Apabila media itu membawa pesan-pesan atau informasi yang bertujuan instruksional atau mengandung maksudmaksud pengajaran maka media itu disebut media pengajaran.

Macam-macam media pembelajaran dalam proses pembelajaran banyak mediamedia yang dapat digunakan, demi terlaksananya proses belajar dan tercapainya tujuan pengajaran, macam-macam media yang dapat digunakan, yaitu: papan tulis, film, buku pelajaran, alat-alat.

C. Prestasi Belajar Siswa

Untuk lebih jelas dalam memahami tentang pengertian prestasi belajar, perlu diketahui terlebih dahulu, apa yang dimaksud dengan belajar. Pada hakikatnya belajar adalah: Menurut Oemar Hamalik adalah "belajar adalah suatu bentuk pertumbuhan atau perubahan dalam diri seseorang yang dinyatakan dalam bentuk cara-cara bertingkah laku yang baru berkat pengalaman dan latihan".

Belajar adalah suatu proses usaha yang dilakukan seseorang untuk memperoleh suatu perubahan tingkah laku yang baru secara menyeluruh dengan hasil pengalamannya sendiri dalam berinteraksi dengan lingkungan. Dari kutipan diatas dapat disimpulkan, bahwa yang dimaksud dengan belajar adalah proses kegiatan yang disertai dengan usaha untuk mencari suatu perubahan pada seseorang dinamakan hasil dari belajar itu disebut prestasi belajar.

D. Faktor-faktor yang Mempengaruhi Prestasi Belajar Siswa

Secara umum faktor yang mempengaruhi prestasi belajar siswa dapat bersumber dari siswa itu sendiri, yang dikatakan dengan faktor intern dan dapat bersumber dari luar diri siswa yang disebut faktor ekstern. 
1. Faktor intern

Faktor intern adalah faktor yang ada dalam diri individu itu sendiri. Adapun yang termasuk faktor intern adalah sebagai berikut:
a Intelegensi
b Bakat
c Minat
d Motivasi
e Kesehatan

2. Faktor ekstern

Faktor ekstern adalah faktor yang berada diluar diri siswa itu sendiri. Adapun yang termasuk faktor-faktor tersebut adalah:

a Lingkungan Keluarga

b Lingkungan Sekolah

c Lingkungan masyarakat

E. konsep virus

1. Sejarah Virus

Virus merupakan benda berukuran kecil dan tidak dapat dilihat oleh mata biasa. Virus hanya dapat dilihat dengan alat yang bernama mikroskop. Mikroskop ini berguna untuk memperbesar kenampakan benda. Benda-benda yang berukuran kecil seperti debu, bakteri, jamur kulit, dan virus akan tampak jelas bila dilihat dengan menggunakan mikroskop.

Sebagaimana Allah SWT berfirman dalam Al-Qur'an (QS. Al-Furqan : 2)

"Dia Telah menciptakan segala sesuatu, dan dia menetapkan ukuranukurannya dengan serapi-rapinya" (QS. AlFurqan : 2)

Berdasarkan ayat di atas dapat dipahami bahwa Allah menciptakan sesuatu dengan segala perlengkapan-perlengkapan dan persiapan-persiapan yang sesuai dengan naluri, sifat-sifat dan fungsinya masingmasing dalam hidup. Dia menetapkan suatu ukuran dan memberikan petunjuk terhadap semua makhluk kepada ketetapan tersebut. Dan itu merupakan ilmu Allah terhadap segala sesuatu sebelum adanya dan pencatatan ketentuan masing-masing makhluk sebelum semuanya tercipta.

\section{Ciri-Ciri Virus}

Virus mempunyai ciri tersendiri. Salah satu ciri virus mirip dengan organisme parasit obligat, yaitu hanya dapat berkembang biak dalam sel hidup. Virus dapat dibiakkan pada ayam berisi embrio hidup. Akan tetapi, berbeda dengan organisme parasit, virus hanya memerlukan asam nukleat untuk mereproduksi dan tidak melakukan aktivitas metabolisme di dalam tubuhnya. Virus bersifat aseluler (tidak mempunyai sel). Virus berukuran tidak jauh lebih kecil dari pada bakteri, yakni berkisar antara 20 milimikron hingga 300 milimikron (1 mikron $=1.000$ milimikron), Virus hanya memiliki satu asam nukleat (RNA atau DNA), Virus umumnya berupa hablur (kristal). Bentuk virus bervarisi. Ada virus berbentuk oval, silinder, polihedral, dan kompleks. Bentuk virus yang kompleks terdiri dari kepala yang berbentuk polihendral, ekor yang berbentuk silinder, dan serabut ekor. Virus berbentuk kompleks misalnya bakteriofag, yaitu jenis virus yang menginfeksi bakteri.

3. Klasifikasi Virus

Virus diklasifikasikan berdasarkan Sifat-sifatnya. Sejumlah informasi yang tersedia didalam setiap kategori tidak sama pada semua virus. Morfologi virion, meliputi: ukuran, bentuk, jenis tangkup. Bagian fisiko kimia virion, meliputi: banyaknya molekul, berat jenis, stabilitas suhu dan tingkat pengaruhnya terhadap kimiawi, khususnya deterjen. Gen virus, meliputi: jenis asam nukleat (RNA atau DNA). Protein virus, meliputi: jumlah, ukuran dan aktivitas fungsional dari protein struktural dan nonstruktural, Organisasi dan replikasi gen, meliputi: jenis gen, jumlah dan posisi kerangka pembacaan terbuka, strategi dari replikasi.

4. Reproduksi Virus

Ada dua macam cara virus menginfeksi bakteri, yaitu secara litik dan secara lisogenik. Pada infeksi secara litik, virus akan menghancurkan sel induk setelah berhasil melakukan reproduksi. Pada infeksi secara lisogenik, virus tidak menghancurkan sel, tetapi berintegrasi dengan DNA sel induk.

5. Peran Virus Dalam Kehidupan

1) Penyakit pada Tumbuhan yang Disebabkan oleh Virus 
Sesungguhnya virus sulit untuk menginfeksi sel tumbuhan karena dilindungi oleh dinding sel. Gejala penyakit tumbuhan yang disebabkan virus antara lain ukuran tanaman nemjadi lebih kurus dan kerdil, timbul bintik atau bercak pada daun, bunga, atau buah dan hasil panen berikutnya.

Berikut ini adalah beberapa penyakit tumbuhan yang disebabkan oleh virus.

a Mosaik, penyakit yang menyebabkan bercak kuning pada daun tembakau, kacang, kedelai, tomat, kentang dan beberapa jenis labu. Penyakit ini disebabkan oleh tobacco musaic virus ( TMV).

b Penyakit kuning yang di sebabkan oleh Begomovirus (bean golden mosaic virus). Tumbuhan yang terkena penyakit virus terhadap tanaman cabe dan buah tomat, dapat dilihat pada gambar 2.1

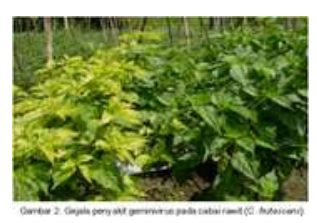

a b

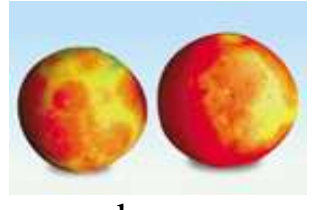

Gambar 2. 1. Tumbuhan cabe dan tomat yang terserang virus

a. Tanaman cabe b. Buah tomat

Sumber:

liadina.wordpress.com/2009/07/02...a-siswa/

c Daun menggulung, terjadi pada tembakau, kapas, dan lobak yang diserang turnip yellow mosaic virus (TYMV). Tumbuhan tembakau dan tanaman tomat yang terserang virus dapat dilihat pada gambar 2.2

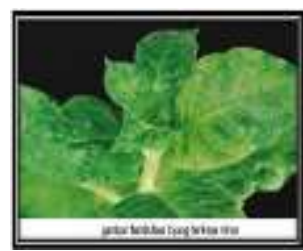

a

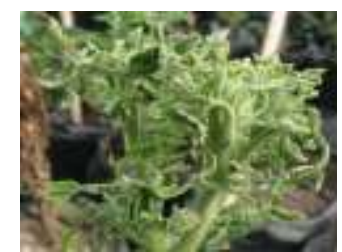

b
Gambar 2.2. Morfologi daun yang menggulung pada tumbuhan yang terserang virus
a. Tanaman tembakau b. Tanaman tomat.

Sumber:

liadina.wordpress.com/2009/07/02...a-siswa/

Tanaman tomat adalah salah satu tanaman yang rentan terkena penyakit yang diakibatkan oleh serangan virus. Selama ini, penyakit virus yang dominan dan seringkali menyerang tanaman tomat adalah tobacco mozaic virus (TMV).

2) Penyakit pada Manusia dan Hewan yang disebabkan oleh Virus

a. Influenza

Influenza merupakan penyakit yang dapat menjalar dengan cepat dilingkunagan masyarakat. Penyebab Influenza adalah virus golongan Orthomyxovirus yang berbentuk seperti bola. Virus influenza ditularkan lewat udara dan masuk ke tubuh manusia melalui alat pernafasan. Virus influensa pada umumnya hanya menyerang sistem pernafasan terutama ditandai oleh demam, mengigil, sakit otot dan sakit kepala. Lamanya sakit berlangsung antara 2-7 hari dan biasanya sembuh sendiri. Yang paling penting menghadapi influenza adalah pencegahan dengan cara memberi kekebalan terhadap infeksi virus yang homoloq, kekebalan yang diperoleh melalui vaksin sekitar $70 \%$. Virus influenza dapat dilihat pada 2.3

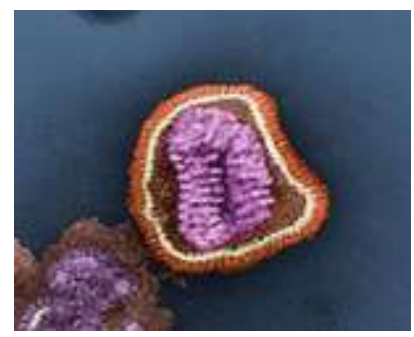

Gambar 2. 3. Virus influenza, dilihat dengan mikroskop elektron.

Sumber http://id.wikipedia.org/wiki/Virus b.Flu burung

Penyakit flu burung atau flu unggas (Bird Flu, Avian influenza) adalah suatu penyakit menular yang disebabkan oleh virus influenza tipe A dan ditularkan oleh unggas. Virus influenza termasuk famili Orthomyxoviridae. Proses penularan virus flu burung terhadap manusia dapat dilihat pada gambar 2.4 


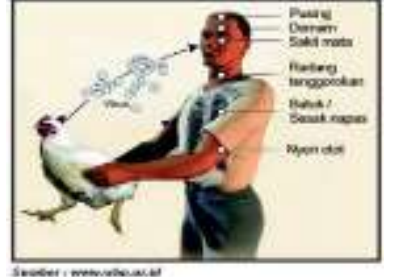

Gambar 2. 4. Proses penularan flu burung ke manusia,

Sumber

http://www.unram.ac.id/2010/04/28/flu-

burung/virus

c. Campak

Campak adalah infeksi saluran pernafasan yang disebabkan oleh virus, penyakit campak mudah menular dan sering menyerang anak-anak, terutama dengan kondisi kurang gizi. Penyakit campak disebabkan oleh virus paramyxovirus yang memasuki tubuh melalui saluran pernapasan bagian atas. Anak yang terinfeksi penyakit campak, dapat dilihat pada gambar 2.5

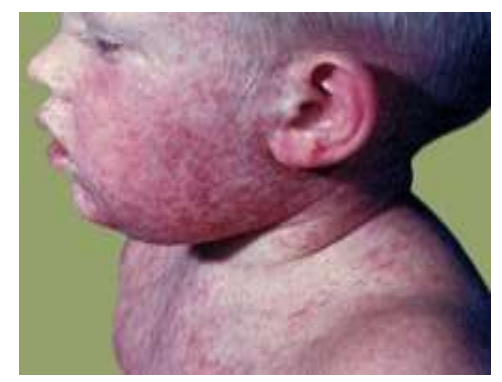

Gambar 2.5. Anak yang terinfeksi virus campak

Sumber:CAMPAK,,Post:Ary_bzx@yahoo.c om (Ari Titin Mulyaningsih,2010)

d.Cacar Air dan Herpes Zoster

Penyakit cacar air atau yang dikenal dengan varisela biasanya ditandai dengan keluhan tubuh mendadak lemas, tak mau makan, demam, dan gatal-gatal, baru setelah muncul erupsi atau kelainan pada kulit, gejala khas penyakit cacar air mulai jelas. Penyebab cacar air adalah virus varicella-zoster. Virus ini ditularkan melalui percikan ludah penderita, bisa juga melalui kontak langsung dengan cairan dari lepuhan kulit penderita atau secara tidak langsung melalui bendabenda yang terkontaminasi oleh cairan lepuhan penderita. Masa inkubasi penyakit cacar air berlangsung 17-21 hari, pada penderita muda, stadium sebelum muncul kelainan kulit muncul (prodormal) jarang dijumpai. Manusia yang terinfeksi penyakit cacar air, dapat dilihat pada gambar 2.6

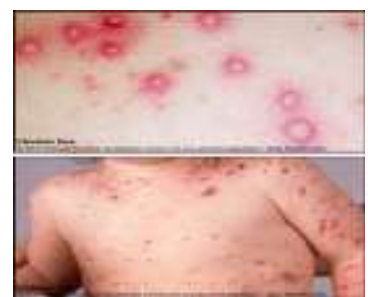

a

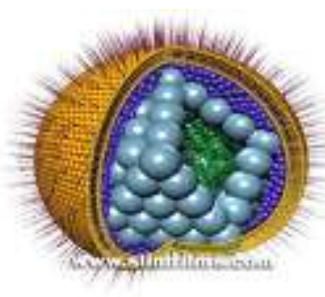

b
Gambar 2. 6 Virus cacar air memiliki selubung virus a. Anak yang terinfeksi cacar air b. Virus cacar air

Sumber

http://www.tanyadokteranda.com/artikel/20 $\underline{07 / 07 / \text { cacar-air }}$

e. Hepatitis

Hepatitis (pembengkakan hati) disebabkan oleh virus hepatitis. Beberapa virus hepatitis yang telah dikenali adalah virus hepatitis A,B,C,D dan E. Gejala umumnya adalah demam, mual, dan muntah, serta perubahan warna kulit dan selaput lendir terlihat kuning.

f. Polio

Polio (poliomyelitis) disebabkan oleh virus polio. Serangan virus polio menyebabkan lumpuh jika virus menginfeksi selaput otak (meninges) dan sumsum tulang belakang. Virus ini menyerang anak-anak berusia 1-5 tahun. Virus polio dapat hidup di air selama berbulan-bulan, sehingga dapat menginfeksi melalui air yang diminum. Dalam keadaan beku, virus ini dapat bertahan hidup sangat lama. Polio dapat menyebar luas diam-diam karena sebagian besar penderita yang terinfeksi polio virus tidak memiliki gejala sehingga tidak tahu kalau mereka sendiri sedang terjangkit.

g. Gondong

Penyakit gondong disebabkan oleh golongan paramyxovirus. Virus ini hanya memiliki RNA. Paramyxovirus dapat tumbuh di jaringan otak, pangkreas, testis, glandula, parotid, dan kadang di hati. Penyakit gondong ditandai dengan 
pembengkakan di belakang kelenjar parotid yang berdekatan dengan telinga karena peradangan akibat infeksi. Gejala lainnya adalah suhu badan $39.50 \mathrm{c}$, demam, sakit kepala, nyeri anggota gerak, dan nyeri otot Penularannya terjadi melalui kontak langsung dengan penderita, melalui ludah, urin, dan muntahan.

h. AIDS

HIV adalah virus golongan retrovirus yang mempunyai 2 molekul RNA. Virus tersebut diduga kuat berasal dari virus kera Afrika yang telah mengalami mutasi. Acuguired immunodeficiency syndrome (AIDS) adalah penurunan sistem kekebalan tubuh yang disebabkan oleh human immunodeficiency virus (HIV).

i. Ebola

Virus Ebola ditemukan pada tahun 1976 di Sudan dan Zaire. Habitatnya di alam di ketahui. Gejala yang ditimbulkan oleh Ebola mirip dengan gejala influenza, yaitu demam, menggigil, sakit kepala, nyeri otot, dan nafsu makan hilang. Gejala ini muncul setelah 3 hari terinfeksi. Pada hari ke-6, darah keluar dari mata, hidung dan telinga. Pada hari ke-9 biasanya penderita meninggal dunia. Ebola ditularkan melalui kontak langsung dengan cairan tubuh penderita ebola, misalnya darah, feses, urin, ludah, dan keringat. Sampai saat ini belum ada penyembuhnya.

j. Herpes Simpleks

Penyakit ini disebabkan oleh virus anggota famili Herpesviridae, yang menyerang kulit dan selaput lendir. Virus herpes simpleks dapat menyerang bayi, anakanak, dan orang dewasa. Penyakit ini biasanya mengenai mata, bibir, mulut, kulit, alat kelamin, dan kadang-kadang otak. Gejala utama adalah timbulnya gelembunggelembung kecil, kecuali pada mata dan otak. k.Rabies

Penyakit ini disebabkan oleh virus rabies, merupakan penyakit yang menyerang hewan, misalnya anjing, kucing, dan kelelawar penghisap darah. Hewan yang terkena gigitan rabies menunjukkan perilaku agresif atau kelumpuhan. Virus ditularkan kepada manusia melalui gigitan hewan yang terinfeksi.

1. SARS

Pernafasan akut parah Severe Acute Respiratory Syndrome (SARS) adalah penyakit saluran pernapasan yang disebabkan oleh virus Coronavirus (CoV).

\section{METODE PENELITIAN \\ Jenis penelitian}

Penelitian ini merupakan penelitian tindakan kelas (Classroom Action Research), yaitu penelitian yang dilakukan pada sebuah kelas untuk mengetahui akibat tindakan yang diterapkan pada suatu subjek penelitian di kelas tersebut. Pada awal penelitian tindakan menjadi salah satu model penelitian yang dilakukan pada bidang pekerjaan tertentu dimana peneliti melakukan pekerjaannya, baik dibidang pendidikan, kesehatan, maupun pengelola sumber daya manusia. Salah satu contoh pekerjaan utama dalam bidang pendidikan adalah mengajar di kelas. Dengan demikian yang menjadi subjek penelitian adalah situasi di kelas, individu siswa, atau di sekolah.

\section{Subjek Penelitian}

Adapun yang menjadi subjek dalam penelitian ini adalah siswa kelas X IPA 2 MAN 4 Pidie yang berjumlah 26 siswa. Pembatasan ruang lingkup ini bertujuan untuk memudahkan peneliti dalam mengumpulkan dan mengelola informasi dikarenakan ruang lingkupnya tidak terlalu luas, di samping itu dengan pembatasan subjek peneliti pada satu kelas, akan menghemat waktu yang peneliti gunakan. Guru memberikan materi virus kepada siswa dengan menggunakan metode questions student have.

Berdasarkan hasil refleksi / masukan pada kegiatan pembelajaran pertama kedua (RPP-2) dengan mengacu pada silabus. Selanjutnya guru melaksanakan proses pembelajaran sesuai RPP-2. Pada saat guru melakukan kegiatan mengajar belajar juga dilakukan pengamatan. Setelah selesai, pengamatan melakukan refleksi yang dapat 
dijadikan pedoman oleh guru dalam merevisi berbagai kelamahan pada RPP-2, sehingga pada RPP-2 ini sudah sangat membaik.

Secara garis besar pelaksanaan penelitian ini dapat digambarkan sebagai berikut.

\section{$\frac{\text { SiklusRancanganPenelitian Tindakan Kelas }}{(\text { a }}$ (Classroom Action Research)}

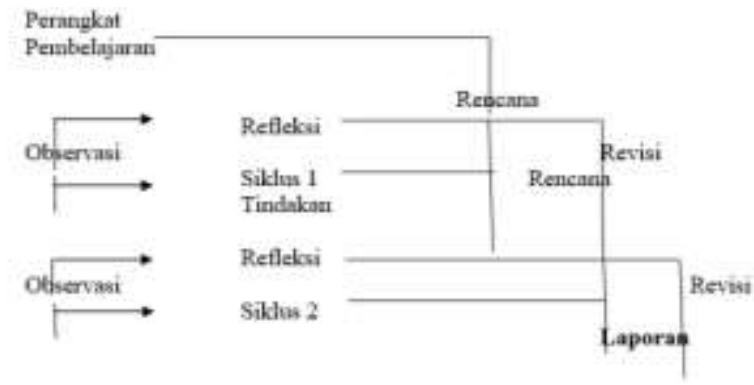

Gambar 3.1 Siklus Rancangan Penelitian Tindak Kelas

Selanjutnya ditentukan tingkat penguasaan siswa pada konsep virus, untuk menentukan golongan tingkat penguasaan siswa, penulis menggunakan klasifikasi penilaian sebagaimana dapat dilihat pada tabel 3.2

Table 3.2Kriteria Penilaian Acuan Patokan

\begin{tabular}{ccc}
\hline No & Angka 100 & Kriteria \\
\hline 1 & $80-100$ & Baik sekali \\
2 & $66-79$ & Baik \\
3 & $56-65$ & Cukup \\
4 & $40-55$ & Kurang \\
5 & $30-39$ & Gagal \\
\hline
\end{tabular}

HASIL PENELITIAN DAN
PEMBAHASAN
Deskripsi Data Hasil Penelitian

1. Hasil aktivitas guru dan siswa pasa RPP I dapat diliahat pada Tabel 4.5.

Tabel 4.5 : Aktivitas Guru Dan Siswa Selama Kegiatan Pembelajaran pada RPP I

\begin{tabular}{|c|c|c|}
\hline No & Aktivitas yang diamati & $\begin{array}{c}\mathrm{RPP} 1 \\
(\%)\end{array}$ \\
\hline \multicolumn{3}{|c|}{ Aktivitas Guru } \\
\hline 1 & $\begin{array}{c}\text { Menjelaskan tujuan } \\
\text { pembelajaran dan } \\
\text { memotivasi siswa dalam } \\
\text { belajar }\end{array}$ & 5,0 \\
\hline 2 & $\begin{array}{l}\text { Menjelaskan secara singkat } \\
\text { tentang pengertian dan } \\
\text { kelasifikasi pada materi } \\
\text { yang akan dipelajari }\end{array}$ & 11,3 \\
\hline 3 & $\begin{array}{l}\text { Mengorganisasi siswa } \\
\text { dalam kelompok belajar }\end{array}$ & 8,8 \\
\hline 4 & $\begin{array}{l}\text { Menjelaskan langkah- } \\
\text { langkah yang ditempuh } \\
\text { siswa dalam proses } \\
\text { pembelajaran }\end{array}$ & 16,3 \\
\hline 5 & $\begin{array}{l}\text { Masing-masing kelompok } \\
\text { diberi tugas berupa LKS } \\
\text { untuk didiskusikan }\end{array}$ & 5,0 \\
\hline 6 & $\begin{array}{l}\text { Membimbing kegiatan } \\
\text { yang dilakukan siswa pada } \\
\text { kerja kelompok secara } \\
\text { bergiliran dan } \\
\text { mengingatkan siswa agar } \\
\text { bekerja secara cermat dan } \\
\text { teliti }\end{array}$ & 8,8 \\
\hline 7 & $\begin{array}{c}\text { Meminta siswa untuk } \\
\text { mempresentasikan hasil } \\
\text { diskusi kelompok kepada } \\
\text { siswa lainnya. }\end{array}$ & 12,5 \\
\hline 8 & $\begin{array}{c}\text { Memberikan kesempatan } \\
\text { kepada siswa untuk } \\
\text { bertanya/mengeluarkan } \\
\text { pendapat dan menjawab } \\
\text { pendapat }\end{array}$ & 10,0 \\
\hline 9 & $\begin{array}{l}\text { Membimbing siswa untuk } \\
\text { menarik kesimpulan secara } \\
\text { tepat terhadap hasil belajar }\end{array}$ & 6,3 \\
\hline 10 & Memberikan latihan & 7,5 \\
\hline \multicolumn{3}{|c|}{ Aktivitas Siswa } \\
\hline 1 & $\begin{array}{l}\text { Mendengarkan penjelasan } \\
\text { guru }\end{array}$ & 6,3 \\
\hline 2 & $\begin{array}{l}\text { Mencatat pengertian dan } \\
\text { klasifikasi serta perbedaan } \\
\text { tentang materi yang } \\
\text { disampaikan guru }\end{array}$ & 11,3 \\
\hline 3 & Mengerjakan soal latihan & 11,3 \\
\hline
\end{tabular}




\begin{tabular}{|c|l|c|}
\hline 4 & $\begin{array}{l}\text { Membentuk dalam } \\
\text { kelompok dan berdiskusi }\end{array}$ & 13,0 \\
\hline 5 & Mengerjakan tugas LKS & 13 \\
\hline 6 & Mengajukan pertanyaan & 11,3 \\
\hline 7 & $\begin{array}{l}\text { Menanggapi pertanyaan } \\
\text { teman }\end{array}$ & 10 \\
\hline 8 & $\begin{array}{l}\text { Menyampaikan } \\
\text { pendapat/ide }\end{array}$ & 11,3 \\
\hline 9 & Menyimpulkan pelajaran & 5,0 \\
\hline 10 & Mengerjakan latihan & 7,5 \\
\hline
\end{tabular}

Sumber: MAN 4 PIDIE 2018 (hasil penelitian)

2. Observasi Kemampuan Guru Mengelola Pembelajaran

Kegiatan pengamatan terhadap kemampuan guru juga dilakukan pada setiap RPP. Hasil pengamatan terhadap kemampuan guru pada RPP I secara jelas disajikan dalam Tabel 4.6 berikut.

Tabel 4.6 : Kemampuan Guru Mengelola Pembelajaran dengan Metode Ceramah

\begin{tabular}{|c|c|c|c|c|c|c|}
\hline \multirow[b]{2}{*}{$\begin{array}{c}\mathrm{N} \\
\mathrm{O}\end{array}$} & \multirow[b]{2}{*}{ Aspek yang diamati } & \multicolumn{5}{|c|}{ RPP-1 } \\
\hline & & $\mathrm{P}_{1}$ & $\mathrm{P}_{2}$ & $\mathrm{X}$ & $\mathrm{Y}$ & $\begin{array}{c}\text { Kateg } \\
\text { ori }\end{array}$ \\
\hline & $\begin{array}{ll}\text { Pendahuluan } \\
\text { 1. } \\
\text { Mengaitkan } \\
\text { pelajaran sekarang } \\
\text { dengan terdahulu }\end{array}$ & $\begin{array}{l}4 \\
3 \\
4\end{array}$ & $\begin{array}{l}3 \\
3 \\
4\end{array}$ & $\begin{array}{l}3,50 \\
3,00 \\
4,00\end{array}$ & 3,50 & Baik \\
\hline & $\begin{array}{l}\text { Kegiatan inti } \\
\text { Memberikan } \\
\text { informasi } \\
\text { pengetahuan langkah } \\
\text { demi langkah } \\
\text { 1. Mendemontrasika } \\
\text { n ketrampilan } \\
\text { dengan benar } \\
\text { 2. Memberikan } \\
\text { latihan terbimbing } \\
\text { 3. Memeriksa } \\
\text { pemahaman dan } \\
\text { memberikan } \\
\text { umpan balik } \\
\text { 4. Memberikan } \\
\text { latihan mandiri }\end{array}$ & $\begin{array}{l}3 \\
4\end{array}$ & $\begin{array}{l}4 \\
3\end{array}$ & $\begin{array}{l}3,00 \\
\\
3,00 \\
3,50 \\
4,00 \\
3,50\end{array}$ & 3,40 & $\begin{array}{l}\text { Hamp } \\
\text { ir } \\
\text { Baik }\end{array}$ \\
\hline & $\begin{array}{l}\text { Penutup } \\
\text { 1. Membimbing } \\
\text { siswa untuk } \\
\text { merangkum } \\
\text { pelajaran } \\
\text { 2. Alokasi dan } \\
\text { penggunaan waktu } \\
\end{array}$ & $\begin{array}{l}3 \\
4\end{array}$ & $\begin{array}{l}3 \\
3\end{array}$ & $\begin{array}{l}3,00 \\
3,50\end{array}$ & 3,25 & $\begin{array}{l}\text { Hamp } \\
\text { ir } \\
\text { Baik }\end{array}$ \\
\hline & $\begin{array}{l}\text { Suasana kelas } \\
\text { 1. Siswa antusias } \\
\text { 2. Guru antusias }\end{array}$ & $\begin{array}{l}3 \\
4\end{array}$ & $\begin{array}{l}3 \\
4\end{array}$ & $\begin{array}{l}3,00 \\
4,00\end{array}$ & 3,33 & $\begin{array}{l}\text { Hamp } \\
\text { ir } \\
\text { Baik }\end{array}$ \\
\hline
\end{tabular}

\begin{tabular}{|c|c|c|c|c|c|c|}
\hline $\begin{array}{l}\text { 3. Pembelajaran } \\
\text { berpusat pada } \\
\text { siswa }\end{array}$ & 3 & 3 & 3,00 & & \\
\hline & Jumlah & 4 & 4 & & & \\
6 & 2 & 44,0 & & \\
\hline
\end{tabular}

Dari tabel diatas dapat kita lihat bahwa kemampuan guru dalam mengelola pembelajaran dalam kelas dengan metode ceramah sudah hampir baik pada setiap aspek yang dilakukan, memotivasi siswa, menyampaikan indikator, memberikan tugas dan merangkum pelajaran. Serta suasana kelas tergolong dalam katagori hampir baik.

3. Hasil belajar siswa

Setelah kegiatan pembelajaran pada RPP II berlangsung, guru kembali meberikan tes/kuis yang diikuti oleh 24 siswa.

4. Refleksi

Selama kegiatan pembelajaran pada RPP I berlangsung, masih terdapat aktivitas siswa yang tidak relevan.

Tabel 4.8: Hasil Temuan dan Revisi Selama Proses Pembelajaran

\begin{tabular}{|c|c|c|c|}
\hline No & Refleksi & Hasil temuan & Revleksi \\
\hline & Siklus I & $\begin{array}{l}\text { Aktivitas } \\
\text { siswa pada } \\
\text { kategori } \\
\text { perilaku yang } \\
\text { tidak relevan } \\
\text { dengan KBM } \\
\text { seperti: } \\
\text { melamun } \\
\text { masih di luar } \\
\text { waktu ideal. }\end{array}$ & $\begin{array}{l}\text { a. Guru } \\
\text { memotivasi } \\
\text { setiap } \\
\text { kelompok } \\
\text { untuk lebih } \\
\text { aktif } \\
\text { berdiskusi } \\
\text { dalam } \\
\text { kelompok } \\
\text { dan lebih } \\
\text { aktif } \\
\text { bertanya. }\end{array}$ \\
\hline & & $\begin{array}{l}\text { Suara guru } \\
\text { masih kurang } \\
\text { jelas } \\
\text { terdengar. }\end{array}$ & $\begin{array}{l}\text { b. Guru } \\
\text { menjelaskan } \\
\text { dengan } \\
\text { suara yang } \\
\text { tegas dan } \\
\text { jelas. }\end{array}$ \\
\hline
\end{tabular}

\section{Tindakan II}

a. Tahap Perencanaan

Tindakan II dilakukan pada tanggal 6 Agustus 2012.

b. Tahap Pelaksanaan (Tindakan)

Kegiatan pembelajaran pada RPP II masih dilakukan dalam tiga tahap dengan 
perbaikan sesuai dengan revisi RPP tindakan I. Pada RPP II ini, siswa tetap bekerja dalam kelompok masing-masing. Kemudian guru memperkenalkan kepada siswa metode pembelajaran Question Student Have (QSH) dan tahap-tahap pembelajarannya serta guru mengulang sedikit materi pada pertemuan sebelumnya dengan meminta salah satu kolompok untuk mendeskripsikan ciri-ciri virus pada hewan dan tumbuhan.

c. Tahap Pengamatan (Observasi)

1) Observasi Aktivitas Guru dan Siswa

Hasil pengamatan aktivitas guru dan siswa pada RPP II dapat dilihat pada Tabel 4.6. Berdasarkan hasil observasi aktivitas guru dan siswa Tabel 4.5 untuk masingmasing kategori pada RPP II sudah efektif.

Tabel 4.9: Aktivitas Siswa Selama Kegiatan Pembelajaran pada RPP II

\begin{tabular}{|c|c|c|}
\hline No & Aktivitas yang diamati & $\begin{array}{c}\text { RPP II } \\
(\%)\end{array}$ \\
\hline \multicolumn{3}{|c|}{ Aktivitas Guru } \\
\hline 1 & $\begin{array}{l}\text { Menjelaskan tujuan pembelajaran } \\
\text { dan memotivasi siswa dalam } \\
\text { belajar }\end{array}$ & 6,3 \\
\hline 2 & $\begin{array}{l}\text { Menjelaskan secara singkat } \\
\text { tentang pengertian dan kelasifikasi } \\
\text { pada materi yang akan dipelajari }\end{array}$ & 13,8 \\
\hline 3 & $\begin{array}{lll}\text { Mengorganisasi } & \text { siswa } & \text { dalam } \\
\text { kelompok belajar } & & \end{array}$ & 17,5 \\
\hline 4 & $\begin{array}{l}\text { Menjelaskan langkah-langkah } \\
\text { yang ditempuh siswa dalam proses } \\
\text { pembelajaran }\end{array}$ & 12,5 \\
\hline 5 & $\begin{array}{l}\text { Masing-masing kelompok } \\
\text { tugas berupa } \\
\text { didiskusikan }\end{array}$ & 12,5 \\
\hline 6 & $\begin{array}{l}\text { Membimbing kegiatan yang } \\
\text { dilakukan siswa pada kerja } \\
\text { kelompok secara bergiliran dan } \\
\text { mengingatkan siswa agar bekerja } \\
\text { secara cermat dan teliti }\end{array}$ & 8,7 \\
\hline 7 & $\begin{array}{l}\text { Meminta siswa untuk } \\
\text { mempresentasikan hasil diskusi } \\
\text { kelompok kepada siswa lainnya. }\end{array}$ & 6,3 \\
\hline 8 & $\begin{array}{l}\text { Memberikan kesempatan kepada } \\
\text { siswa untuk bertanya/ } \\
\text { mengeluarkan pendapat dan } \\
\text { menjawab pendapat }\end{array}$ & 10 \\
\hline 9 & $\begin{array}{l}\text { Membimbing siswa untuk menarik } \\
\text { kesimpulan secara tepat terhadap } \\
\text { hasil belajar }\end{array}$ & 6,3 \\
\hline 10 & Memberikan latihan & 6,3 \\
\hline
\end{tabular}

\begin{tabular}{|c|l|c|}
\hline \multicolumn{2}{|l|}{ Aktivitas Siswa } & \\
\hline 1 & Mendengarkan penjelasan guru & 8 \\
\hline 2 & $\begin{array}{l}\text { Mencatat pengertian dan } \\
\text { klasifikasi serta perbedaan tentang } \\
\text { materi yang disampaikan guru }\end{array}$ & 8,8 \\
\hline 3 & Mengerjakan soal latihan & 13 \\
\hline 4 & $\begin{array}{l}\text { Membentuk dalam kelompok dan } \\
\text { berdiskusi }\end{array}$ & 13 \\
\hline 5 & Mengerjakan tugas LKS & 15 \\
\hline 6 & Mengajukan pertanyaan & 10 \\
\hline 7 & Menanggapi pertanyaan teman & 10 \\
\hline 8 & Menyampaikan pendapat/ide & 8,8 \\
\hline 9 & Menyimpulkan pelajaran & 8,8 \\
\hline 10 & Mengerjakan latihan & 6,3 \\
\hline
\end{tabular}

Sumber: MAN 4 PIDIE 2018 (hasil penelitian

2) Observasi Kemampuan Guru Mengelola Pembelajaran

Fokus pengamatan dikelompokan menjadi kegiatan pendahuluan, kegiatan inti, penutup, kemampuan mengelola waktu, dan suasana kelas. Berdasarkan hasil observasi terhadap kemampuan guru mengelola pembelajaran menggunakan metode question student have pada RPP II sudah kategori sangat baik.

Tabel 4.10 : Kemampuan guru Mengelola Pembelajaran dengan Metode Question Student Have pada RPP II.

\begin{tabular}{|c|c|c|c|c|c|c|}
\hline \multirow[b]{2}{*}{ No } & \multirow[b]{2}{*}{ Aspek yang diamati } & \multicolumn{5}{|c|}{ RPP-2 } \\
\hline & & $\mathrm{P}_{1}$ & $\mathrm{P}_{2}$ & $\mathrm{X}$ & $\mathrm{Y}$ & $\begin{array}{c}\text { Kateg } \\
\text { ori }\end{array}$ \\
\hline & $\begin{array}{l}\text { Pendahuluan } \\
\text { 1. } \text { Mengaitkan pelajaran } \\
\text { sekarang dengan } \\
\text { terdahulu } \\
\text { 2. Menyampaikan } \\
\text { indikator } \\
\text { 3. Memotivasi } \\
\end{array}$ & $\begin{array}{l}3 \\
4 \\
3\end{array}$ & $\begin{array}{l}4 \\
4 \\
3\end{array}$ & $\begin{array}{l}3,50 \\
4,00 \\
3,00\end{array}$ & 3,50 & Baik \\
\hline & \begin{tabular}{l}
\multicolumn{1}{c}{ Kegiatan inti } \\
1. Memberikan \\
informasi \\
pengetahuan langkah \\
demi langkah \\
2. Mendemontrasikan \\
ketrampilan dengan \\
benar \\
3. Memberikan latihan \\
terbimbing \\
4. Memeriksa \\
pemahaman dan \\
memberikan umpan \\
balik \\
5. $\begin{array}{l}\text { Memberikan latihan } \\
\text { mandiri }\end{array}$
\end{tabular} & $\begin{array}{l}4 \\
4\end{array}$ & $\begin{array}{l}4 \\
4\end{array}$ & $\begin{array}{l}3,00 \\
4,00 \\
4,00 \\
4,00 \\
4,00\end{array}$ & 3,80 & $\begin{array}{c}\text { San } \\
\text { gat } \\
\text { Baik }\end{array}$ \\
\hline
\end{tabular}




\begin{tabular}{|c|c|c|c|c|c|}
\hline \begin{tabular}{|l}
\multicolumn{1}{c}{ Penutup } \\
1. Membimbing siswa \\
untuk merangkum \\
pelajaran \\
2. Alokasi dan \\
penggunaan waktu
\end{tabular} & $\begin{array}{l}4 \\
4\end{array}$ & $\begin{array}{l}4 \\
4\end{array}$ & $\begin{array}{l}4,00 \\
4,00\end{array}$ & 4,00 & $\begin{array}{c}\text { San } \\
\text { gat } \\
\text { Baik }\end{array}$ \\
\hline $\begin{array}{l}\quad \text { Suasana kelas } \\
\text { 1. Siswa antusias } \\
\text { 2. Guru antusias } \\
\text { 3. Pembelajaran berpusat } \\
\text { pada siswa }\end{array}$ & $\begin{array}{l}4 \\
4 \\
4\end{array}$ & $\begin{array}{l}4 \\
3 \\
4\end{array}$ & $\begin{array}{l}3,00 \\
4,00 \\
3,00\end{array}$ & 3,83 & $\begin{array}{c}\text { San } \\
\text { gat } \\
\text { Baik }\end{array}$ \\
\hline Jumlah & 49 & 49 & 49,0 & & \\
\hline
\end{tabular}

\section{3) Hasil Belajar Siswa}

Setelah kegiatan pembelajaran pada RPP II berlangsung, guru kembali meberikan tes/kuis yang diikuti oleh 24 siswa. d. Refleksi

Tabel 4.12 Hasil Temuan dan Revisi Selama Proses Pembelajaran

\begin{tabular}{|c|l|l|l|}
\hline No & Refleksi & Hasil temuan & Revleksi \\
\hline 1. & Siklus II & $\begin{array}{l}\text { a. Aktivitas guru } \\
\text { dan siswa pada } \\
\text { tindakan II } \\
\text { sudah termasuk } \\
\text { dalam kategori } \\
\text { sanagt baik }\end{array}$ & $\begin{array}{l}\text { a. Penjelasan metode } \\
\text { question student } \\
\text { have bias menjadi } \\
\text { salah satu } \\
\text { alternatif dalam } \\
\text { mengajarkan } \\
\text { Biologi. }\end{array}$ \\
\hline & & $\begin{array}{l}\text { b.Siswa semakin } \\
\text { aktif dalam } \\
\text { diskusi } \\
\text { menjawab LKS } \\
\text { biologi bidang studi } \\
\text { memberikan dapat } \\
\text { bimbingan yang } \\
\text { lebih kepada siswa } \\
\text { yang lebih kepada } \\
\text { siswa yang belum } \\
\text { tuntas belajar }\end{array}$ \\
\hline & & c. Suasana kelas & \\
& & semakin \\
& & & \\
\hline & & & \\
\hline
\end{tabular}

Berdasarkan tabel 4.9 di atas dapat diketahui bahwa 26 siswa (100\%) tuntas belajarnya, berdasarkan KKM yang ditetapkan di MAN 4 Pidie khususnya bidang studi Biologi bahwa siswa dikatakan tuntas bila memiliki daya serap $65 \%$. Dengan tuntunan yang demikian maka guru sudah menjadi efektif dan efisien bagi siswa di kelas tersebut tuntas belajarnya.

\section{Tinjauan Terhadap Hipotesis}

Hipotesis yang diajukan dalam penelitian ini adalah: Penerapan pembelajaran dengan menggunakan metode question student have dapat meningkatkan prestasi belajar siswa pada konsep virus dan penyakit pada tumbuhan dan hewan.

\section{Pembahasan}

Penelitian ini adalah penelitian tindakan kelas (PTK) yang dilakukan dengan tujuan untuk melihat prestasi siswa melalui metode questions student have. Berdasarkan hasil belajar siswa yang diperoleh dalam setiap pertemuan dan berdasarkan tes akhir, siswa sudah mencapai ketuntasan balajar secara klasikal disetiap pertemuan. Demikian juga dengan hasil tes akhir siswa yang termasuk dalam kategori tuntas dengan perolehan nilai yang sesuai dengan KKM (Kriteria Ketuntasan Ketuntasan Belajar) yaitu 65. Hal ini dikarenakan siswa sudah memahami materi virus. Pencapaian keberhasilan belajar ini tidak lepas dari usaha guru dalam memotivasi siswa untuk bisa lebih antusiasi dan terlibat dalam setiap pertemuan. Selain itu, guru juga mampu melaksanakan dengan baik setiap proses dan langkah-langkah pembelajaran yang berorientasi kepada model pembelajaran yang diterapkan. Adapun media yang digunakan adalah baut, tang dan kawat yang dibuat bentuk rangka virus dalam materi virus sehingga siswa dapat memahami materi yang bersifat abstrak.

Berdasarkan hasil pegolahan data terlihat bahwa kemampuan guru dalam mengelola pembelajaran berada pada kategori sangat baik sesuai dengan perolehan nilai 3,80. Hal ini karena guru yang merupakan peneliti sudah mempersiapkan perangkat pembalajaran question student have secara cermat. Kemampuan guru melakukan perbaikan-perbaikan melalui refleksi setelah pertemuan pembelajaran berlangsung merupakan faktor penting agar dapat lebih baik pada pertemuan berikutnya.

Selama pembelajaran berlangsung, aktivitas guru dan siswa termasuk dalam kategori aktif, hal ini disebabkan karena LKS membantu siswa untuk menyelesaikan masalah dengan kerja secara berkempok. Hal ini sesuai dengan dengan pendapat Conny 
Semiawan "siswa yang pandai dapat memberikan bantuan belajar kapada siswa yang kurang pandai". Bantuan tersebut dapat dilakukan dalam diskusi kelompok. Selama kegiatan pembelajar pada siklus I berlangsung, masih terdapat aktivitas siswa yang tidak relevan (malawan). Oleh karena itu, guru perlu memberikan motivasi pada setiap kelompok untuk lebih aktif berdiskusi dan merespon pertanyaan tamannya.

Selama kegiatan pembelajaran pada siklus II Aktivitas guru dan siswa pada tingkat III termasuk dalam kategori sangat baik. Sehingga metode ini bias diterapkan untuk materi virus. Respon yang diberikan siswa terhadap pembelajaran materi virus dengan menggunakan metode pembelajaran question student have sangat baik. Hal ini sesuai dengan hasil angket dengan nilai 83,33 $\%$ yang menyatakan bahwa senang terhadap kegiatan pembelajaran tersebut. Rasa sengang siswa terhadap pembelajaran menunjukkan bahwa pembelajaran ini menimbulkan rasa puas bagi siswa. Rasa senang siswa juga disebabkan oleh untuk bekerja sama dalam kelomok dalam menyelesaikan tugas pada LKS dengan persentase $15 \%$ pada setiap RPP.

\section{Kesimpulan}

Berdasarkan hasil penelitian tentang penerapan metode question student have dapat disimpulkan:

1. Dari hasil jawaban respon/tanggapan siswa terhadap soal-soal yang telah diberikan, siswa dominan menjawab senang belajar dengan penerapkan metode question student havepada pembelajaran materi virus dan penyakit pada tumbuhan dan hewan di MAN 4 Pidie.

2. Penerapkan metode question student have dapat meningkatkan prestasi belajar siswa pada pembelajaran konsep virus.

3. Respon siswa terhadap penerapan metode question student havepada umumnya siswa senang dan berminat untuk mengikuti pembelajaran yang baru diikuti.

\section{Saran-saran}

Berdasarkan hasil yang diperoleh dari penelitian ini, peneliti dapat memberikan saran-saran sebagai berikut:

1. Penerapan metode question student havedalam bidang studi biologi mempunyai pengaruh yang positif dalam meningkatkan hasil belajar siswa, maka diharapkan kepada guru bidang studi agar dapat menerapkan metode question student havedalam pembelajaran konsepkonsep biologi lainnya.

2. Pembelajaran biologi dengan menerapkan metode question student havemembutuhkan keterampilan khusus dan professional guru untuk merancang metode question student have sederhana sebagai alternatif untuk dapat terciptanya kegiatan mandiri, oleh karena itu kepada guru bidang studi yang bersangkutan diharapkan dapat meningkatkan keterampilan dan profesionalisme untuk dapat merancang metode-metode pembelajaran yang mudah dipahami siswa dalam pembelajaran biologi, supaya tidak terkesan membosankan dan dipenuhi dengan gambar-gambar.

3. Hasil penelitian ini hendaknya dapat menjadi bahan masukan bagi guru biologipada khususnya dan guru bidang studi lain pada umumnya dalam upaya peningkatan mutu pendidikan.

4. Disarankan kepada pihak lain untuk melakukan penelitian yang sama pada materi lain sebagai bahan perbandingan dengan hasil penelitian ini.

\section{DAFTAR PUSTAKA}

Anas Sudijono, Pengantar Statistik Pendidikan, Jakarta: Rajawali Pers, 1992.

Aristiawan Nugroho, Pembelajaran
Questiont Student Have.
Surakarta:2009.


Azhar Arsyad, Media Pembelajaran. Raja Grafindo Persada, Jakarta, 1997.

Cece Wijaya dan A. Tabrani Rusyan, Kemampuan Dasar Guru dalam Proses Belajar Mengajar, Bandung: Remaja Renda Karya,1994.

Fedik A. Rantam, VIROLOGI, Cet.1. Surabaya, Airlangga University, 2005.

Hadari Nawawi, Pengaruh Hubungan Manusia Dikalangan Murid Terhadap Prestasi Belajar di SD, Analisis Pendidikan, Jakarta ; Depdikbud, 1970.

http://jamumanjur.com/herbal/campak$\underline{\text { measles }}$

http://lehawir.blogspot.com/2010/10/berbagi -ilmu-proposal-question-students.html

Jewetz, Mikrobiologi Kedokteran, Jakarta: Salemba Medika,2005.

Judi Al-Faransi dan Fauzan Naif, Kunci Sukses Belajar, Semarang: Aneka Ilmu, 1984.

Kartini Kartono, Bimbingan Belajar Di SMA dan Pengaruh Tinggi, Jakarta: C.V Rajawali, 1985.

Martensi dan Mungin Edi Wibowo, Identifikasi Kesulitan Belajar, Semarang: IKIP, 1980.

Moh. Surya, Psikologi Pendidikan, Bandung: IKIP,1981.

Muhibbin Syah, Psikologi Belajar, Jakarta : Logos, 1999.
Mulyasa, menjadi guru professional, (Bandung, PT Remaja Rosda Karya, 2005 .

Nasution, Tehnologi Pendidikan, Jakarta, Bumi, 1994.

Oemar Hamalik, Metode Belajar dan Kesulitan-kesulitan Belajar, Bandung: Tarsito, 1983.

Pelezar, Dasar-dasar Mikrobiologi. Universitas Indonesia, UL-Press. 2005.

Raharja, Umar Tirta, Pengantar Pendidikan, Jakarta: Rineka Cipta, 1995.

Sibelmen, Active Learning 101 cara belajar siswa aktif, Cet. 111, Bandung: Nuansa, 2006.

Slamento, Belajar dan Faktor-faktor yang mempengaruhinya, Cet. III, Jakarta: Rineka Cipta, 1995.

Sudoyo. Aru W, Ilmu Penyakit Dalam Jilid 3 Edisi 4 Jakarta, Juli 2006.

Sugiarti, Biologi, Jakarta: Ganeca Exact, 2007.

Suharsimi Arikunto, Penelitian Tindaka Kelas, Jakarta: Bumi Aksara, 2008.

Syah, Muhibbin, Psikologi Pendidikan dengan Pendekatan Baru, Bandung: Remaja Rosda Karya, 2003.

The Liang Gie, Cara Belajar yang Efisien, Yogyakarta: UGM, 1981.

Trimaryati, kk, IPA Biologi Jakarta Erlangga 2006. 